\title{
Good Living as an Alternative to the Young Entrepreneurship. An Evaluation from Social Relationship and Productions Perspective
}

\author{
Tannia Cristina Poveda Morales', José Fabián Fonseca Vásconez ${ }^{2}$, Reynol Hernández Maden³, \\ Juan Bladimir Aguilar Poaquiza² \\ ${ }^{1}$ Uniandes University, Ambato, Ecuador \\ ${ }^{2}$ Espoch University, Riobamba, Ecuador \\ ${ }^{3}$ Matanzas University, Matanzas, Cuba \\ Email: cristypoveda@hotmail.com, fabian.fonseca@espoch.edu.ec, reynol.hernandez@umcc.cu, jaguilar2016@hotmail.com
}

How to cite this paper: Morales, T.C.P., Vásconez, J.F.F., Maden, R.H. and Poaquiza, J.B.A. (2016) Good Living as an Alternative to the Young Entrepreneurship. An Evaluation from Social Relationship and Productions Perspective. Open Journal of Sociai Sciences, 4, 87-98.

http://dx.doi.org/10.4236/jss.2016.49009

Received: August 2, 2016

Accepted: September 18, 2016

Published: September 21, 2016

Copyright $\odot 2016$ by authors and Scientific Research Publishing Inc. This work is licensed under the Creative Commons Attribution International License (CC BY 4.0).

http://creativecommons.org/licenses/by/4.0/

\begin{abstract}
The need to promote the review, the structure and restructuring of scientific alternatives and economic models for creating companies claiming the preservation of the planet and create better living conditions for humanity can be considered as possible solutions to the overexploitation of the planet and the inequitable distribution of wealth, which has led to economic and social crisis, present in vulnerable populations, youth unemployment and the lack of jobs do not guarantee a lifestyle based on dignity and development. This study focuses on theoretical methods, historical-logical analysis, inductive-deductive analysis, and chart analysis to understand relevant facts and phenomena during the investigation of young entrepreneurs in the case study. The scope of this study lies in identifying the elements involved in the intention to undertake the influential features in this process, which is a contribution to future entrepreneurs.
\end{abstract}

\section{Keywords}

Good Living, Entrepreneurship, Political Economy, Theories of Development

\section{Introduction}

Currently one of the major challenges facing the society and the economy of this new millennium is undoubtedly the growth, sustainment, and development of social and economic structures at the local level, constituting the development and economic growth in a research topic and analysis of humans, so there have been various ideologi- 
cal trends throughout the course of existence of mankind, theories have their own parameters to delineate economic growth, knowledge as an antecedent being essential to explain, analyze and properly interpret its principles and economic structures, to find a path to human development and sustained economic growth.

Likewise the various problems caused by global warming, have promoted various scientific studies and establishment of policies whose approaches define that economic growth is in harmony with the natural environment and population, why and in correspondence to the issue raised this research aims to explain the natural perspective of Good Living as an alternative to development and correlate with the various conceptual thesis oriented economic development and the concept of sustainability, to assess its impact from the social relations of production.

We all need to be aware that economic development must serve the human being and therefore to society, based on respect for the fundamental differences where there is harmony between man, nature and society. So if the goal is to create an economic model in which social wealth is distributed in a more equitable manner, and that will meet the needs of all the inhabitants of the country, it is essential that the means of production involving all sectors, or at least the means of production [1].

This research uses the theoretical method, established relevant facts and to understand phenomena throughout the research process. (Analysis-Synthesis, induction-deduction, hypothetical-deductive, historical-Logical Modeling, System approach, analysis Tables), which will be used to study the issue raised. In this sense, this study aims to establish an analysis of the development and trends of Good Living to promote a correlation with the theories of development and entrepreneurship from a political and economic approach.

\section{Development}

\subsection{Natural Perspective of Good Life as an Alternative to Development}

The rebellion and the struggle of indigenous peoples occurred in several parts of Latin America, to oppression and inequalities at the hands of Western civilization, implanted to claim their right to develop proposing an alternative to traditional nation-state approach on development; whose historical and philosophical legacy emerges in response to failure and weakening of market-centric development and economic growth neoliberal policies; which are central to development and economic growth. Continuing with that line of thought, "in terms that the Western positivism is understood as a reflection, that is, as an analytical concept that can position the interior of coherently structured framework concepts, which since the Enlightenment, have been called science" [2]. In this sense the Good Life or Sumak Kawsay (SK) collects ancestral forms of life of indigenous peoples of the Americas, especially the indigenous movements of Ecuadorian and Bolivian ancestors, whose approach state that the population should live in a healthy and ecologically balanced environment that ensures sustainability, in compliance with ethical and moral principles, such as: Ama Qhilla (do not be lazy), Ama Llulla (do not be a liar), Ama Suwa (don't be a thief), Suma Qamaña (live well) 
Ñandereko (harmonious life), Tekokavi (good life), Ivimaraei (land without evil), Qhapajñan (noble path or life), Ayllu (family), Ayllu Llakta (commune), Minka (collective work), Rimanakuy (practice of dialogue), Yuyarinakuy (agreements), Pacha Mama (nature); proponents of life of indigenous communities seek to set up a progressive state and a pluralistic society "seeks delicate and complex socioeconomic and environmental balances, under a strong process of social legitimation" [3]. Knowledge considered marginalized or prohibited inciting the emancipation of peoples and a possible reestablishment of the state, whose form of ancient life based on simple principles such as complementarity, reciprocity and national diversity, subverts the current order of Western thought that puts man as the center of the universe recovering humanity, to support a social coexistence in diversity.

It coincides with [4], considering that Good Living is an ideological trend that emerges from isolation which was the subject for more than five centuries and now promotes political and academic reflection for intellectuals and critics of various types of ideologies are attracted to this new political, economic, legal and natural alternative to development alternative.

In this regard, the Good Life is not an alternative for development but development, considering that there is no vision of a state of underdevelopment to be overcome in the "indigenous worldview. And neither a state of development to be achieved by forcing the destruction of social relations and harmony with Nature" [5]. It is this ideological trend promotes "building a different form of production, distribution and consumption, far from the parameters and paradigms of current economic thought, which has made the notions of development, economic growth, market, relative prices, among other not concepts or working hypothesis, but at the same transcendent reality" [6].

Financial crisis, food, irrational use of energy with a logic of limitless growth, migration, unemployment, human misery, climate change, constitute neuralgic contemporary issues worldwide, guide us to ask what to do and how to do it? Questions that emphasize the importance and contribution of Good Living, whose philosophical spur of Latin American indigenous peoples, aim to recover the harmonious relationship between humans and their environment, between humanity and their peers; proposal that determines and reprograms the understanding of progress, which is often misunderstood as the accumulation of goods, thus questioning the basic notion of economic growth where merchandise is the hub of all economic activity. In this sense, reconfigures the political structures to pass the monocultural matrix, the social construction of plurinational and intercultural attitudes with full recognition of the unity in diversity; as well as it has been demonstrated in investigations by various authors who have delved into the subject [7]-[9].

Houtart's vision is shared (2012), considering that in the short term, from a philosophical approach Good Living contains the basis for guiding both common sense and criticism of the capitalist mode of development, in the medium term regionalization of economies that would find synergies, providing guarantees against repetitive crises and recovery of natural resources, and long-term propositions may seem utopian, because 
they are often difficult to implement and involve changes in philosophical order because it is not only a question of rationality but as well as social struggle.

That is, it is imperative the to sustain the use of natural resources for the long term, the use value over exchange value, the spread of democracy, multiculturalism, also considered as the core of social construction plurinationality by its context. This orientation and new rationality can build an alternative development visions -based on central market have failed, to focus, in some cases, to be only visions central state; becoming an economy with no market and a market economy [7] characterized by:

\subsubsection{Generalization of Democracy}

It is the social responsibility of every human conglomerate organized that each of its members is actively involved in the assets of each activity for the sole purpose of preventing the loss of creditability of representative democracy. This is done to extend the responsibility of each citizen, "the application of many possible formulas such as: participatory budgeting, accountability or even referenda, transparency in integration processes, characterized by the dialectic between creativity and organization" [10].

\subsubsection{Intercultural Relationships}

The subordination between cultures, has led to profound processes of social exclusion, economic inequality, discrimination and lack of conception and the general context of societies, therefore multiculturalism proposes dialogue between equals, taking the best of each society and economic systems. That is, multiculturalism becomes one of the most convenient ways to overcome the development and transition to Good Living [8] [11].

\subsubsection{The Use Value over Exchange Value}

Concepts that were devised by Marx, understood as use value, which has an object to satisfy a need, from the biological necessity such as eating, to even the most spiritual such as those relating to leisure and the world of culture. The exchange value is the value that an object has on the market and this has become the norm of society. Thus, it is necessary that the predominance of use value the duration of the life of the products should be extended, the extension would use less raw materials and less energy, producing less waste and therefore better protecting the natural environment as well reducing the influence of financial capital [10].

\subsubsection{Plurinationality}

Plurinationality is the idea to promote the existence of multiple nations in one state, and understanding that the concept of multi-nationality is a "fundamental part to analyze and subvert the economic and political systems, which ultimately promote Good Living, because of the content of its principles grounded on complementarity, reciprocity, similarity, and correspondence" [12].

\subsubsection{The Sustainable Use of Natural Resources}

In search of developing countries as poor as the rich, devastated by the globalization trend that promotes competitiveness, sometimes indiscriminately, have incurred the 
excessive exploitation of natural resources; so governments have been decisive, taking away rights from Nature [7], which in a political context means they encourage their transition from object to subject, to rescue the right to exist of human beings themselves. Sumak Kawsay proposes the incorporation of nature into history, not as a productive factor or as a productive force but as an inherent part of being social. She proposes various epistemological frameworks that considers the existence of circular time that can coexist with linear time of modernity.

Establishing an analysis of the Sumak Kawsay, a critical notion of conventional development is understood as economic growth. It coincides with [2] and [13], considering that progressive governments continue to exploit nature pursuing economic growth but at the same time establish active public policies related to education, health, social welfare, and even environmental compensation. It is of great importance the discovery and analysis of economic laws that determine the development of society give theoretical and coherent response to new trends and paradigms of economic development. Which are characterized by increased social welfare, the same constitutes one the objectives of any society. The development of society was founded on the economic laws, which expresses diversity of in relations of production [14].

\subsection{Scientific Perspectives and Conceptual Thesis, Aimed to Economic Development and the Concept of Sustainability}

Economic development will always be a difficult problem to solve for all peoples of the world, taking into consideration that human beings are rarely ever satisfied and resources are exhaustible. Given this diverse scenario, scientific perspectives have been implemented into the consideration of company philosophies, in order to maximize the use and benefit of the factors of production contributing to maintain economic and social prosperity, eradicating poverty and eliminating poverty. The concept of development is so well known that once a taxonomy was implemented between regions developed regions of the world and others that were referred to as underdeveloped, or more politely "developing". There was, and stillis, an extensive literature about establishing a series of recommendations to the so-called underdeveloped countries as to overcome this condition and imitate those countries, which had achieved development [2].

According to [15], a country cannot be considered to be in economic growth if this growth does not lead to a reduction in the number of poor and indigenous, so that the conditions of inequality are minimized. Historical processes have ratified the law of uneven development, confirmed by Marxism, especially its theoretical enrichment Lenin. This uneven development occurs worldwide, with the concentration of wealth and technology in highly industrialized economies of the West, at the expense of the underdeveloped countries of the Third World or the South, which euphemistically call them developing. If what has been described is true, you can also say that the global uneven development is growing between rich and poor countries.

This is the political economy and he or she who studies and unravels the laws that govern the development, production relations among men, in the process of production of material goods, whose laws govern the production and distribution of material goods 
in human society along various stages of development [14]; it is necessary to understand that modes of production, is the alloy of the productive forces and production relations.

The relations of production have led to the intellectual debate through its design and intrinsic nature, of each during different development processes, which are grounded in ideological thoughts that have influenced the dimensions of world history. In this sense, the present study considers relevance in analyzing approaches to development of liberalism, Keynesianism and Marxism, being validated ideological tendencies and bases of new paradigms for development and sustainability.

\subsubsection{Focus of Liberalism to Economic Development}

It being understood that liberalism as an economic doctrine that considers the minimum state interference in the economy, and that its origin of being structured in a systematic way comes from exhibitors as "J. Locke, D. Hume, A. Smith, A. Ferguson, E. Bunker, H. Espencer, L. Acton, J. B. Say, B. Constant, and W. von Houmboldt” [16] (Benegas Lynch, 2009). Authors such as Marchesi and Navalpotro (2002) [17] believe that liberalism is a social and political theory that can achieve economic progress of society and material well-being, taking the State to be limited to four functions: 1) promoting economic freedom; 2) encourage private investment; 3 ) provide services of general interest; 4) provide limited security.

Liberalism believes that the market is the most effective way to coordinate liberalization arrangements, the various plans of individuals whose welfare is achieved when they enjoy the greatest possible freedom, so that they can use their ideas and their economic resources as they see fit. In this sense Adam Smith (1759), believes that the market has the ability to regulate itself according to the theory of the Invisible Hand.

In this trend, the developing countries need to achieve development through capitalism through several phases the developed countries went through, that is to say increased production, accumulating wealth and technological innovation, which would help meet the needs of the population; economic growth system that imposes its liberal thinking Laissez Faire, Laissez Passer, maximum understood as stopping, or letting go. From the theory of liberalism, ideological roots to the structuring of neoliberalism and post-neoliberalism [18] are set. It coincides with [19], in which the criteria of the classical theory are averse to apply them to real facts, because its principles are only applicable to a special case, different from the real economic situation.

\subsubsection{Keynesianism and Its Approach to the Economic Development}

Post-liberalism there was the Keynesian approach, in the decade of the $30 \mathrm{~s}$, in response to the failure of economic liberalism that hindered the development of countries; this product of the Great Depression arose. The crisis of overproduction had emerged as the main danger of capitalist economy, imperialism and consolidated its position as the new phase of development and internationalization of economic relations unfolded [20]. The ideological thinking of John Maynard Keynes, embodied in his "General Theory of Employment, Interest and Money", focused its analysis on aggregate demand 
that related to employment and income, to keep the economic sectors in balance. [21]; for which the state should not focus only on the momentum of expansionary fiscal policies, but also in making investments in public works to generate new jobs.

In this regard, the development suggested by Keynes in the capitalist approach, at the time that saw the light of his theory leads us to understand that the road to development is productivity, whose goal is the power of the bourgeois class income; which was criticized by Marx (1950), who said that capitalism is a social system of production whose logic operation depends on the motivation of profit.

\subsubsection{Marxist Approach to Economic Development}

Karl Heinrich Marx, the father and banner of men with socialistic ideologies with his main work "Capital", and his theory is widely known, as Marxism was a critic of the supposed dictatorship called bourgeois capitalist dictatorship. He states that developed countries hinder the development of developing countries.

Socioeconomic relations among men, is the basis of development, at any stage of development to be found, production has always had two aspects, the productive forces and production relations. Marx points out that economic times are distinguishable from each other not from how they occur, but the instruments used in the production of material goods, it can be understood that work is a rational human activity aimed at the production of material goods apart.

Marxist philosophy focuses its analysis on the goods, considered as the core of capitalist society, with the aim of giving a logical order, from which Marxism proposes a series of stages or steps to be followed to achieve a developed human society, to eliminate inequalities, a radical change in economies that produced surplus value, needed to consolidate the socialist state still needed. A system where the intellectual and scientific minds understand the reality around us, allowing man to achieve better living standards [22].

It coincides with [2], saying that Marxist theory in his speech development was part of a vision that assumed the totality of capitalism as a historically determined system, in which there were social relations of production at the global level, sustained by imperialism.

\subsection{Synthesis of Sustainable Development as a Paradigm for Development}

Sustainable development has its origins in 1972 in the publication of the Report to the Club of Rome "Limits to Growth", a report on the predicament of mankind, which indicated the existence of physical limits to growth, which is due to foreseeable depletion of natural resources and overall inability to assimilate the waste of the planet [23]. After holding twenty years in the international debate, through the report prepared in 1987 by the Brundtland Commission defined Sustainable Development as one that provides the needs of the present generation without compromising the ability of future generations to meet their own needs.

Currently, in speaking of development many forms and definitions (endogenous de- 
velopment, local, sustainable, human-scale), are aimed at obtaining territorial competitiveness and risk management to ensure the safety of the middle social units, economic activities, infrastructure, services and promoted environment. In this sense it agrees with [24], who cites some theorists who argue that sustainable development is to sustain natural resources (Carpenter, 1991), sustain consumption levels (Redclift, 1987), or achieve sustainability resources, human capital, physical capital and environmental resources (Bojo 1990). Moreover, [25], changes the classic view of the concept of sustainable development to consider four areas: ecological, economic, social, and institutional, for the analysis of territorial realities of the physical and social world in which regulatory and legal factors are framed.

Most interpretations of sustainable development, agree that the forms and actions to achieve economic efficiency must respect the environment and be socially balanced as an alternative to models that have led to environmental degradation, from the search for creative responses to correcting failures and preventing further problems, always seeking mediation and negotiation to facilitate dialogue between stakeholders with different objectives.

\subsection{Discussion}

\section{Sumak Kawsay in Social Relations of Production}

The economic crisis that humanity has suffered as a result of imbalance in the relations of production and productive forces have caused a brake on development, problems analyzed by social laws governing the production and distribution to meet human needs. For this reason every time a reference is made to productivity relations, we understand in the academic field of social sciences and economics analysis the issue is political economy.

In this sense when the macro and microeconomic variables are analyzed in different structured cycles periods, it can be determined that the crisis of capitalism is integral, because it "covers the financial crisis, the real crisis clinic, the energy crisis, the food crisis, the ecological crisis, the aggressive foreign policy crisis, the ideological crisis, the moral crisis, the crisis of governance, the crisis of rampant consumerism, the crisis of political economy, which mixes neoliberalism and recipes Keynes, before discarded.

Interventionism posed as anti-humanitarian is a dilemma that blind forces. Invisible Hands control and automatically regularize the market, own the ideologies of a liberal approach to development, which promotes the capitalist mode of production, economic system in which the control of production and the distribution of real and financial resources are based on private ownership of the means of production. From the perspective of Marxism, the purpose of economic theories is to uncover the mechanism through which capitalism acts as a system of exploitation and prove that capitalism, like all economic systems that preceded it inevitably generates forces that lead to its destruction and replacement [26]. Being essential to identify the scientific theory, Marx focused on the laws governing capitalist production, becoming Marxists postulated as 
the main critics of capitalism.

Overcoming poverty is the moral imperative of society and the economy, whose developmental objective is to provide all human beings the opportunity to live a full life, and these are the needs of fundamental development (Streeten, 1981) [27]. While what has been cited above is true, it also coincides with the Marxist theory that considers further development as a political problem than a purely economic issue.

From the perspective of political economy, liberals, neoliberals and Keynesians ideologues have failed to define the problem of existing economic crisis in the world, and have not been able to prevent them; history confirms that the search for alternatives for development has been established after major crises, so that sustainable development is an alternative for development without damaging or depleting the resources that make it possible. As the genesis of a new paradigm, critical of capitalism and its methods for development around different visions, projects and policies in search of equality, solidarity and harmony, suggest that economic growth is the means to improve the existence of humans through a process of opportunities to promote a healthy life, access to education, to live in harmony and respect for the rights of nature, and respect for multiculturalism and multi-nationality, the Andean peoples propose Sumak Kawsay, or Good Living, which "is not just a criticism but a proposal to the development of great significance, of great complexity and that is not exhausted in a short-term" [3].

Table 1 shows the characterization of business development of the city of Ambato, Ecuador located in the province of Tungurahua. The figures (2015) show that of all of the entrepreneurs in the city there is a great inclusion of women, most of whom are owners of established businesses in the sector analysis, these being $66 \%$ commercial and $20 \%$ service charge. Ambato being the cantonal capital of the province, and found in the central region, welcomes many visitors, traders and consumers, which has led owners to focus on improving the conditions of production and marketing; taking into account one of the major factors in the Sumak Kawsay, as is nature. In addition, the study identified that $42 \%$ of business nature care as a priority factor is assumed, this being very encouraging figure, as it denotes the existence of awareness.

Moreover, the level of education reflects a high figure in regard to tertiary studies that have interviewed entrepreneurs (33\%); and $41 \%$ with secondary education, and interests continue training to improve their function and management within established businesses. With respect to breaking the vicious circle of poverty and social exclusion, it has been promoted entrepreneurship and business creation for young people, where ages prevailing in this study were as ranging from 25 to 39 years, which have been considered as young adults according to the ILO in January 2015.

It coincides with [28] (Mariátegui Flores, 2006), saying that socialism in Latin America does not have to be a carbon copy of other socialist countries; It should be the heroic creation, giving life to their own reality in their own language the Indo-American socialism. In this sense the Sumak Kawsay and the opinion of the authors, it could also be called Socialism of Good Living, because like socialism, are doctrines of social, collective rights defenders. 
Table 1. Characterization of business development of the city of Ambato under the proposals of Sumak Kawsay, 2015.

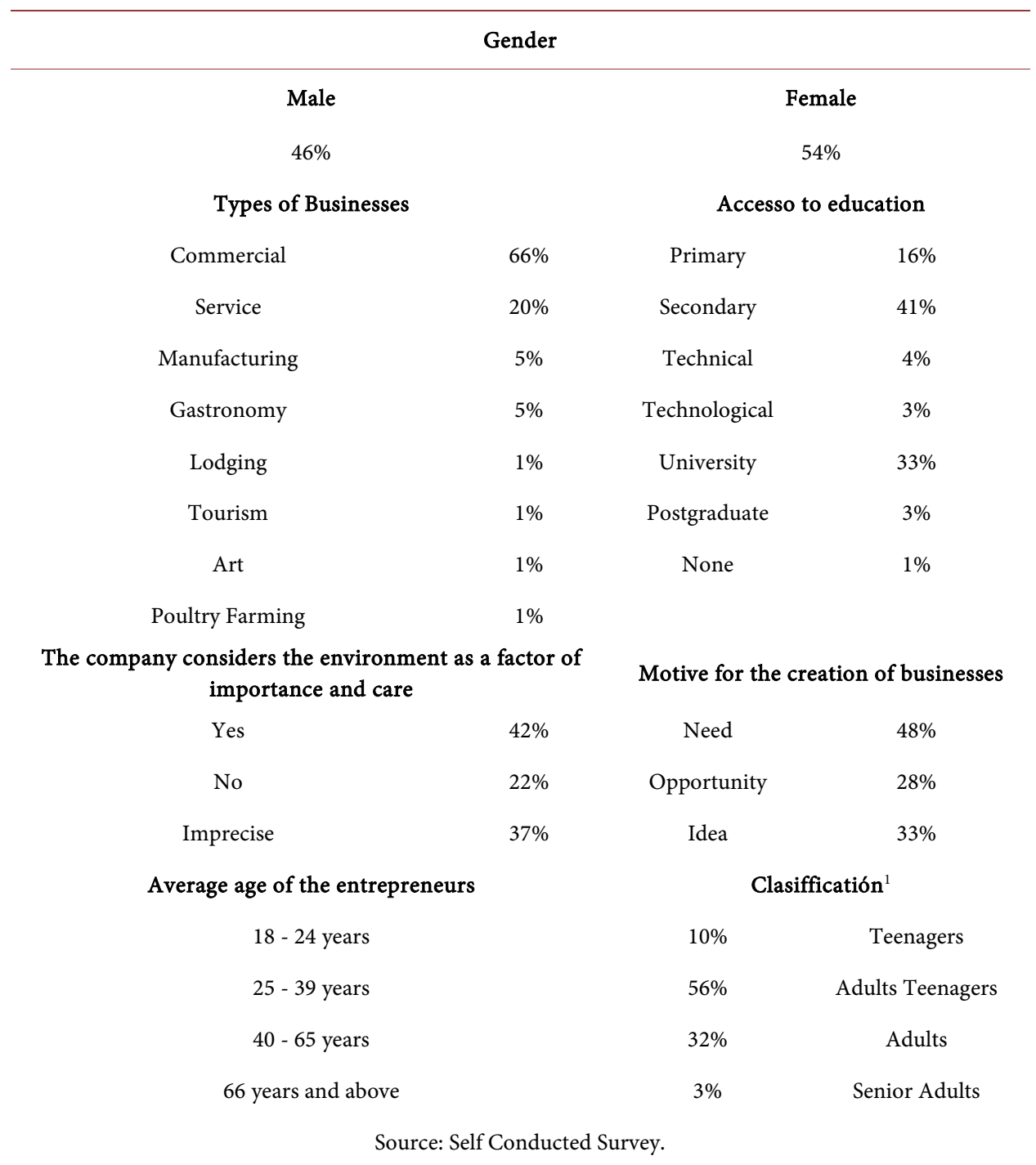

${ }^{1}$ In the reviewed literature they have been similarities and slight differences among age groups; Thus, for example, Lassio et al. (2013) in a study on Early Entrepreneurial Activity classify those young people between the ages of 15 and 24, and from 25 to 65 years as adults; in which also coincided ILO (2015). This same organization in the report Global Employement Trends for Youth 2015 (ILO, 2015) states that regional and global age defined as young ranges from 15 to 24 years and the age called young adult ranges from 25 to 29 years, making this an exception in developed economies where young ranges from 15 to 29 years. However, this report also concludes that the adult population is considered young up to 40 years old.

\section{Conclusions}

- While capitalism has failed, the development of the relations of production does not correspond to the level of productive forces; it is necessary from the understanding that development is a financial socio-economic and non-economic issue, in which participatory democratic structures is considered and inclusive.

- The Good Life generates a path to the second independence of Latin American peoples, changing the way society thinks about economic growth, which must come 
from the relations of men in production, distribution and consumption.

- Good Living Socialism combines the two transitions: from capitalism to socialism, colonialism and decolonization, ending racism, extermination and cultural inferiority; strengthens the criteria of liberal democracy by establishing participatory democracy and community, also recognizes the rights of nature, and demonstrates the importance of the knowledge of indigenous peoples, to create a process of inclusive socialism (De Souza Santos, 2012) [29].

- Respect for multiculturalism and nationality, in the economic system, through solidarity, consolidation and the inclusion of new popular political subjects, encourages the creation of a model economy where the market agreed with the preservation of environment.

\section{References}

[1] Harnecker, M. (2010) The New Economic Model of the Socialism of the 21st Century. Some Elements for the Discussion, SENPLADES, The New Challenges of Latin America: Socialism and Sumak Kawsay, Quito, Ecuador, 77-89.

[2] Dávalos, P. (2011) Sumak Kawsay (The Life in Fullness). To Coexist to Last: Conflicts Ecosociales and Ecological Wisdoms, Ed. Icaria, 201-214.

[3] Álvarez, S. and Cendrero, J. (2013) Sumak Kawsay or Goog Living as Alternative to the Development in Ecuador. Application and Results in the Government of Rafael Correa (20072011). Thesis of Doctorate Complutensian University of Madrid, Spain.

[4] Bretón, V., Cortez, D. and García, F. (2014) In Search of the Sumak Kawsay, Icons-Magazines of Social Sciences, 9-24.

[5] Arkonada, K., Alcoreza, R., Pazos, J. and Acosta, A. (2012) A State, Many Peoples (Villages): The Construction of the Plurinacionalidad in Bolivia and Ecuador. Icaria, Quito, Ecuador.

[6] Latorre, F. and Ramos, C. (2002) Economic Growth in a Context of Sustainable Development. Commercial Spanish Information, ICE: Revista de Economía, 47-64.

[7] Acosta, A. (2013) Presentation of the Good Living in Barcelona. https://www.youtube.com/watch?v=5g4OwmDljOE

[8] Chuji, M. (2009) Modernity, Development, Interculturalidad and Sumak Kawsay or Good to Live, Presentation (Paper) Presented in the International Forum on Interculturalidad and Development. Through Uribia, Colombia.

[9] Dávalos, P. (2008) Think about the Sumak Kawsay (Good to Live) and the Theories of the Development, Conference ALAI (Agency Latin American Informations), Quito, Ecuador.

[10] Houtart, F. (2012) Sumak Kausay's Concept (Good to Live) and His (Her, Your) Correspondence with the Common Good of the Humanity (Central Topic). Magazine Specialized in Social Sciences, 57-76.

[11] Larrea, A. (2008) The Plurinacionalidad. Equal and Diverse in Search of the Sumak Kawsay. Revista Entre Voces, 35-40.

[12] García, F. and Cañizares, S. (2010) Analysis of the Enterprising Profile: A Perspective of Kind (Genre), Studies of Applied (Hardworking) Economy.

[13] Cortez, D. (2010) Genealogy of "Good to Live" in the New Ecuadoran Constitution. VIII International Congress for Intercultural Philosophy. Good Life as Humanized Life, Ewha Womans University, Seoul.

[14] Nikitin, P. (2007) Politycal Economy. Santa Fe, Bogotá. 
[15] Ortiz, I. (2007) Social Politics (Policy). Guides of Orientation of Public Policies. National Strategies of Development. Close (United) Nations Department of Economic Affairs and Social (DAES), New York.

[16] Benegas Lynch, A. (2009) Foundations of Economic Analysis. Undecima, Buenos Aires.

[17] Marchesi, J. and Navalpotro, J. (2002) Ethics, Economic Growth and Human Development. Trotta.

[18] Hernández, J. (2007) Liberalism, Neoliberalism, Postneoliberalism. Magazine Mad, 66-89.

[19] Martel, M. (2006) From the General Economy to the Financial Economy: A Comment, Magazine to Introduce Journal Revista of Administrative and Social Sciences. 7-24.

[20] Lara, Y. (2007) The Economic Thought of John Maynard Keynes and Milton Friedman. A Study of His(Her, Your) Theories across 4 Central Problems. Magazine Contributions to the Economy.

[21] Figueroa, F. (2007) Keynes’s Legacy. Magazine Contribuciones a la Economía.

[22] Lopes, D. and García, E. (2015) Salamansa: The Approaches of the Local Development. Sociological Approximations. Magazine Contributions to the Social Sciences.

[23] Mesino Rivero, L. (2010) The Fiscal Policies and His(Her, Your) Impact in the Social Well-Being of the Venezuelan Population. An Analysis from the Critical Paradigm. Period: 1988-2006. http://www.eumed.net/tesis-doctorales/2010/lmr/indice.htm

[24] Fernández, I. (2014) The Concept of Sustainable Development. www.ecoportal.net/content/view/full/36818

[25] Taddei, L. (2011) Possibilities and Challenges of the Sustainable Development in the Region Tacna. Thesis Conferred a Doctor's Degree National University Federico Villarreal.

[26] Páramo, P. and Otálvaro, G. (2006) Alternative Investigation (research): For a Distinction between(among) Positions(Attitudes) Epistemológicas and Not between(among) Methods. Moebio’s Tape, Epistemología's Magazine of Social Sciences.

[27] Streeten, P. (1981) The First Thing Is the First Thing: To Satisfy the Human Basic Needs in The Developing Countries. Publicado Banco Mundial, Washington DC (EUA).

[28] Flores, J. (2006) Jose Carlos Mariátegui’s Thought. Part(Report) II, Magazine Theory and Practice.

[29] De Souza Santos, B. (2012) The Socialism of the Good One to Live. Latin-American Agenda. 
Submit or recommend next manuscript to SCIRP and we will provide best service for you:

Accepting pre-submission inquiries through Email, Facebook, LinkedIn, Twitter, etc. A wide selection of journals (inclusive of 9 subjects, more than 200 journals)

Providing 24-hour high-quality service

User-friendly online submission system

Fair and swift peer-review system

Efficient typesetting and proofreading procedure

Display of the result of downloads and visits, as well as the number of cited articles

Maximum dissemination of your research work

Submit your manuscript at: http://papersubmission.scirp.org/

Or contact jss@scirp.org 